\& Research Square

\title{
Assessment of Hygiene Practices and Microbial Safety of Milk Supplied by Smallholder Farmers to Processors in Selected Counties in Kenya
}

\author{
Miriam W. Mogotu \\ University of Nairobi \\ George 0. Abong \\ University of Nairobi \\ John Mburu \\ University of Nairobi
}

Asaah 0. Ndambi ( $\nabla$ asaah.ndambi@wur.nl)

Wageningen University \& Research https://orcid.org/0000-0001-8563-2805

\section{Research Article}

Keywords: Collection channels, E-coli, Listeria, milk quality, total viable counts, Staphylococcus

Posted Date: June 28th, 2021

DOI: https://doi.org/10.21203/rs.3.rs-599169/v1

License: (9) (i) This work is licensed under a Creative Commons Attribution 4.0 International License. Read Full License 


\section{Abstract}

Smallholder farmers dominate the Kenyan dairy sector producing $95 \%$ of the total milk. However, several concerns have been raised on the quality and safety of the milk they produce. This study assessed the hygienic practices and microbial safety of milk supplied by smallholder farmers to processors in Bomet, Nyeri, and Nakuru counties in Kenya. Interviews and direct observations were carried out to assess hygiene and handling practices by farmers and a total of 92 milk samples were collected along four collection channels: direct suppliers, traders, cooperatives with coolers and cooperatives without coolers. Microbial analysis was done following standard procedures and data analysed using GenStat and SPSS. This study revealed that farmers did not employ good hygienic practices in their routine dairy management. They used plastic containers for milking and milk storage (34.2\%); they did not clean sheds (47.9\%) and did not set aside cows that suffered from mastitis factors (83.6\%), resulting in poor microbial quality of raw milk along the collection channels. The highest mean total viable counts $\left(8.72 \log _{10} \mathrm{cfu} / \mathrm{ml}\right)$ were recorded in Nakuru while Nyeri had the highest mean E. coli counts $\left(4.97 \log _{10} \mathrm{cfu} / \mathrm{ml}\right)$ and Bomet recorded the highest mean counts of 5.13 and $5.78 \log _{10} \mathrm{cfu} / \mathrm{ml}$ for Staphylococcus aureus and Listeria monocytogenes respectively. Based on all above-mentioned parameters, the microbial load in most samples from all three counties exceeded the set Kenyan standards. Farmer training, improving road infrastructure, use of instant coolers at cooperatives, and quality-based payment systems are recommended as measures to curb microbial growth.

\section{Introduction}

Kenya's dairy sector has a significant socio-economic role in the national economy. It is a source of livelihood and nutrition for many, generating about $4 \%$ of the national GDP and has been ranked among the largest in sub-Saharan Africa (KDB 2020). Small scale farmers dominate the dairy industry at production level (Bonilla et al. 2018) where they produce over $95 \%$ of the national milk produced (KDB 2020). Dairy production in Kenya is mainly practiced in the highlands and is mostly intensive or semi-intensive farming (Bonilla et al. 2018). Dairy herds in Kenya comprise of an estimated 3.3 million head of pure-bred Fresian Holstein, Ayshire, Guernsey, Jersey, and other crosses which produce over 3 billion litres of milk per year (TIAPD, 2016).

Milk produced by small-scale dairy farmers is consumed both in urban and rural areas and is a necessity for most Kenyans (Alonso et al. 2018). Milk has a relatively short shelf life thus requires quick and efficient marketing to ensure optimum results (KDB 2020). There has been great emphasis on the organization of small-scale milk producers into groups such as self-help groups, cooperatives, and companies to enhance efficiency in the marketing of raw milk with dairy cooperatives dominating the marketing of milk (KDB 2020). Milk processing capacity in Kenya is also on a steady growth owing to the growing demand of milk and dairy products with new milk processors coming up in different counties who source milk from farmers within the community (KNBS 2020).

As much as there is increased demand, processing, and marketing of milk, there still remains a challenge of noncompliance with national, regional, and international quality and safety standards (Bebe et al., 2018). This is mainly due to the lack of efficient monitoring and proper enforcement structures in the country.

Milk marketed in the formal and informal sectors in Kenya often does not meet the set microbial standards, posing a health hazard (Knight-jones et al. 2016). Milk and dairy products are rich in nutrients making them a good environment for the growth of both spoilage and pathogenic microorganisms (Alonso and Grace 2018).

To reduce milk spoilage, more dairy cooperatives have been established where farmers bulk and cool their milk before it is marketed or transported to processors (Odero-Waitituh, 2017). There has also been an increase in the number of middlemen or traders who bulk milk from several farmers and transport it to the cooperatives or processors. While some have helped in ensuring the efficiency of milk transportation, most have brought more complications in the traceability of milk (Bonilla et al. 2018). 
There is a need to assess the hygiene knowledge and handling practices of milk by farmers considering that milk contamination usually begins at the production level and given that the microbial safety of raw milk in Kenya from smallscale farmers has been a grave concern for decades (Knight-jones et al. 2016; Alonso et al. 2018; Brown et al. 2018). Understanding the various socio-demographic characteristics of the respondents will provide additional knowledge on how they influence hygiene knowledge and handling practices of milk by farmers. Presence of middle men or traders further complicates the traceability of milk and brings a risk of cross-contamination and microbial overload due to poor milk handling by transporters, adulteration of milk and in some cases long transportation time without refrigeration (Vara Martínez et al. 2017). There is also limited data on the microbial quality of milk along collection channels despite the need for monitoring from production to consumption (Ndungu et al. 2016a).

\section{Materials And Methods \\ Study site}

The study was carried out in Bomet, Nakuru and Nyeri counties in Kenya (Figure I). Agriculture is the main economic activity in the three counties with dairy farming dominating (KDB 2020). In Bomet, most farmers practice semi-intensive dairy farming where cows are allowed to graze in the fields during the day and housed in stalls at night (CGOB 2019) due to larger size of land in the area while in Nakuru and Nyeri farmers practice intensive dairy farming due to higher population and smaller land sizes (CGONY 2019; CGON 2020). Each county has several milk processors and cooperatives where farmers bulk and market their milk.

\section{Study design}

The study applied a cross-sectional sampling design involving a household survey to understand hygiene practices and laboratory analysis of milk samples for milk microbial quality. The survey was on smallholder dairy farm households within the three counties from July 2019 to December 2019.

\section{Sampling procedure for the household survey}

The study targeted farmers supplying milk to three types of milk processors: government owned, private processor, and farmer or cooperative owned. These processors were also selected based on their willingness to participate in the study. The target population for the household survey was dairy farmers who supplied milk directly to the selected processors in the three counties in 2018. A list of these farmers was obtained from each processor and exhaustive sampling (selecting the population since it was small) was done.

\section{Sampling of Milk for Microbial Analysis}

Raw milk samples were collected from three counties: Bomet, Nyeri and Nakuru. Milk samples were collected along four major channels:

(1) Farmers who supplied milk directly to processors (direct suppliers),

(2) Traders who bulked milk from several farmers and transported it to cooperatives,

(3) Cooperatives which delivered bulked milk from farmers to processors using their own means of transportation

(4) Cooperatives from which processors collected bulked milk using their own transportation tankers.

However, not all four channels were found in each of the three counties. Bomet had direct suppliers, a cooperative (Coop 1) which delivered bulked milk using its own transportation means and a cooperative (Coop 2) from which the processor collected the bulked milk. Nakuru had direct suppliers, traders, and two cooperatives (Coop 3 and 4) from which the processor collected the bulk milk. Nyeri had direct suppliers, a cooperative (Coop 5) which delivered bulk milk using its own transportation means and cooperatives (Coop 6 and 7) from which the processor collected the bulked milk. There were two types of cooperatives: those with coolers (Coop 1, 2, 3, 4, and 7) and those without (Coop 5 and 6). 
Table 1

Sampling distribution for the three counties

\begin{tabular}{|lllll|}
\hline $\begin{array}{l}\text { County } \\
\text { No. of samples }\end{array}$ & Bomet & Nakuru & Nyeri & Total \\
\hline Direct Suppliers & 26 & 18 & 26 & 70 \\
\hline Coop with cooler & 6 & 6 & 3 & 15 \\
\hline Coop without cooler & 0 & 0 & 4 & 4 \\
\hline Traders & 0 & 3 & 0 & 3 \\
\hline Total & $\mathbf{3 2}$ & $\mathbf{2 7}$ & $\mathbf{3 3}$ & $\mathbf{9 2}$ \\
\hline
\end{tabular}

An exhaustive sampling, i.e., selection of the population was done for direct suppliers where 26 samples were collected in Bomet, 18 in Nakuru, and 26 in Nyeri. Exhaustive sampling was also done for traders and cooperatives who supplied milk to the three processors. Three samples were obtained from traders in Nakuru. Three samples were obtained from each cooperative that possessed coolers and two samples were obtained from each cooperative without coolers. A total of 92 samples were obtained: 32 from Bomet, 27 from Nakuru, and 33 from Nyeri as shown in Table I.

\section{Ethical considerations}

Local chiefs who are the relevant and highest government authority in each location and sublocation where the study was carried out in the counties were consulted before beginning the household survey. Interviews and milk samples were obtained only from farmers who consented. Farmers, cooperatives, and transporters were assured of the confidentiality of the data obtained since individual names are not included in the paper.

\section{Interviews of direct suppliers of milk in the counties}

A pretested semi- structured questionnaire was administered to farmers to assess knowledge and practices regarding milk hygiene. In addition, direct observations were carried out at the farms on farm hygiene, dairy herd management, cleanliness of milking equipment, and farm personnel. A total of 73 randomly sampled milk suppliers were interviewed at the household level, comprising 27, 23 and 23 from Bomet, Nakuru, and Nyeri counties, respectively.

\section{Procedure for obtaining Milk Samples}

All samples were aseptically collected after thorough stirring of the cans, containers, troughs, coolers, and tankers. The samples were collected as shown in Fig. 2.

\section{a) Direct suppliers}

Milk samples were tightly closed, labelled, and immediately kept in a cool box. They were then transported to the University of Nairobi, Department of Food Science Nutrition and Technology laboratory where they were stored at four degrees Celsius and analysed within 24 hours.

\section{Microbial analyses}

\section{Sample preparation}

Serial dilutions were prepared according to ISO 6887-1 procedure (ISO, 1999). To obtain 15\% Buffered Peptone Water (BPW), $15 \mathrm{~g}$ of BPW powder was dissolved in 1 litre of distilled water according to the manufacturer's instructions (OXOID \& Ltd., Basingstoke, Hampshire, England) and sterilised in the autoclave. Samples were removed from cold storage and allowed for 30 minutes to attain room temperature. They were then thoroughly shaken and using a sterile pipette, $1 \mathrm{ml}$ of the sample was transferred into a sterile falcon tube containing $9 \mathrm{ml}$ of BPW $\left(10^{-1}\right.$ dilution), which was followed by serial dilutions as shown 
in Fig. 3. The procedure was repeated up to $10^{-7}$ dilution and in the last dilution $1 \mathrm{ml}$ of inoculum was discarded. The dilutions were mixed thoroughly before they were used to enumerate: TVC, E. coli, S, aureus and L. monocytogenes.

\section{Enumeration of Total Viable Counts}

Total viable counts were enumerated as per ISO 4833 (ISO, 2001). Dilutions of $10^{-5}$ to $10^{-7}$ of homogenate samples were poured into sterile petri dishes in duplicate and sterile Standard Plate Count Agar was added. Plates were covered, gentle sufficient shaking was done, and after drying they were inverted and incubated at $37 \otimes \mathrm{C}$ for 24 hours. A colony counter was used to count plates with colonies ranging from 30 to 300 , which were expressed as colony forming units per ml of the sample (CFU/ml).

\section{Enumeration of Staphylococcus aureus}

Staphylococcus aureus was enumerated as per ISO 6888-1:1999 (ISO, 1999). Dilutions of $10^{-2}$ to $10^{-4}$ of homogenate samples were pipetted on the surface of previously dried Baird-Parker agar plates in duplicates and spread with a sterile bent glass rod. Plates were incubated at $37 \rrbracket C$ for 24 hours. Enumeration was done using a colony counter where the colony forming units were expressed per $\mathrm{ml}$ of the sample (CFU/ml). The colonies were identified based on colour which was black and shiny, with narrow white margins, surrounded by clear zones extending into the opaque medium.

\section{Enumeration of Escherichia coli}

Escherichia coli was enumerated as per ISO 16649-2:2001 (ISO, 2001). Dilutions of $10^{-2}$ to $10^{-4}$ of homogenate samples were pipetted on to sterile plates in duplicates, sterile HiCrome agar was added, and gentle sufficient shaking was done. After drying, the plates were inverted and incubated at $37 \otimes C$ for 24 hours. Enumeration was then done using a colony counter where colony forming units were expressed per $\mathrm{ml}$ of sample (CFU/ml) for colonies which had bluish green colour.

\section{Enumeration of Listeria monocytogens}

Listeria monocytogens was enumerated as per ISO 10560 (ISO, 2001). Dilutions of $10^{-2}$ to $10^{-4}$ of homogenate samples were pipetted onto the surface of dried Listeria chromogenic agar in duplicate and spread with a sterile bent glass rod. Plates were inverted and incubated at $37 \mathbb{\triangle C}$ for 24 hours. Enumeration was done using a colony counter for colony forming units on colonies which had blue to blue- green colour and expressed per $\mathrm{ml}$ of sample (CFU/ml).

\section{Data analysis}

Household survey data was analysed using descriptive statistics where Statistical Package for the Social Sciences (SPSS) version 22 (SPSS Inc., Chicago, IL, USA) was used to analyse farmer data on hygienic practices. Significant differences in sociodemographic characteristics, knowledge, and hygiene practices in the various counties were tested using one-way ANOVA at $95 \%$ confidence interval. Associations between sociodemographic characteristics and knowledge on hygiene practices in the various counties were tested using $\mathrm{Chi}^{2}$. Laboratory data was analysed using GenStat version 15 where mean differences were separated by the least significant difference procedure using Tukey's formula.

\section{Results}

\section{Sociodemographic characteristics of the respondents}

Sociodemographic characteristics of direct suppliers are as represented in Table 2. There was no significant difference ( $p>$ 0.05 ) in gender, age of respondents in all categories, marital status in terms of being married or living with spouse, and level of education of respondents at the elementary and middle school level. However, there was a significant difference $(p<0.05)$ in the farming system practised in the counties where most farmers (92.3\%) in Bomet practiced semi-intensive farming while $83.3 \%$ and $100 \%$ of farmers in Nakuru and Nyeri respectively practised intensive farming. 
Table 2 Sociodemographic Characteristics (percent respondents) of direct suppliers in Bomet, Nakuru, and Nyeri Counties

\begin{tabular}{|c|c|c|c|c|}
\hline Characteristic & Bomet & Nakuru & Nyeri & Total \\
\hline \multicolumn{5}{|l|}{ Gender } \\
\hline Male & 61.5 & 44.4 & 65.4 & 57.5 \\
\hline Female & 38.5 & 55.6 & 34.6 & 42.5 \\
\hline \multicolumn{5}{|l|}{ Age (years) } \\
\hline $18-35$ & 26.9 & 27.8 & 11.5 & 22.1 \\
\hline $35-50$ & 42.3 & 38.9 & 38.5 & 39.9 \\
\hline$>50$ & 34.6 & 33.3 & 50.0 & 38.0 \\
\hline \multicolumn{5}{|l|}{ Education level } \\
\hline No formal education & 3.8 & 22.2 & 0.0 & 8.2 \\
\hline Elementary & 30.8 & 38.9 & 50.0 & 39.7 \\
\hline Middle school & 50.0 & 38.9 & 19.2 & 37.0 \\
\hline High school & 11.5 & 0.0 & 30.8 & 15.1 \\
\hline University & 0.0 & 0.0 & 0.0 & 0.0 \\
\hline \multicolumn{5}{|l|}{ Marital status } \\
\hline Married & 80.8 & 77.8 & 73.1 & 76.7 \\
\hline Single & 19.2 & 0.0 & 11.5 & 12.3 \\
\hline Divorced & 0.0 & 0.0 & 3.8 & 1.4 \\
\hline Widow/er & 0.0 & 22.2 & 11.5 & 9.6 \\
\hline \multicolumn{5}{|l|}{ Farm system } \\
\hline Intensive & 7.7 & 83.3 & 100 & 60.3 \\
\hline Semi-intensive & 92.3 & 16.7 & 0.0 & 39.7 \\
\hline
\end{tabular}

\section{Milk handling and hygienic practices}

Different handling and hygiene practices were observed in farmers in the three counties (Figure 4). There was a significant difference $(p<0.05)$ in the type of milking containers used by farmers in the three counties. Most used plastic containers for milking and transportation of milk with Nakuru recording the highest where $56 \%$ of the farmers used plastic. There was also a significant difference $(p<0.05)$ in cleaning of the sheds, use of reusable cleaning cloths to clean udders, and setting aside cows with mastitis in the three counties. While the farmers in Nyeri and Nakuru applied more hygienic practices in cleaning the cow shed and udders in comparison to farmers in Bomet, about half of the farmers in Bomet set aside mastitis cows, while none of their counterparts in Nyeri and Nakuru did the same. These practices are important in that they directly affect 
milk quality. There was no significant difference $(p>0.05)$ in refrigeration of milk by farmers and the time they took to deliver milk to the processors.

In Bomet, there was a significant association $\left(X^{2}=16.759, p<0.05\right)$ between the level of education of the respondents and the type of milking can they used. Additionally, in Bomet there was a significant association $\left(X^{2}=17.944, p<0.05\right)$ between the type of farming practised by the respondents and cleaning of sheds.

Cleaning practices for milk containers and udder were similar in Nakuru and Nyeri where (almost) all farmers always cleaned their containers and used a cleaning cloth for the udder (Table 3). This was different in Bomet which brought about a significant difference $(p>0.05)$ in the cleaning of milk containers in the three counties. It was found that all the farmers in Nyeri always cleaned milking containers however; most of them (41.4\%) used water only to clean the containers while $20.7 \%$ used water with disinfectants. Cleaning of udders varied significantly $(p<0.05)$ in the three counties where almost half (43.5\%) of farmers in Bomet used their bare hands to clean udders while most farmers in Nakuru and Nyeri used a cleaning cloth.

Table 3 Cleaning Practices of Farmers (percent respondents) in the Various Counties

\begin{tabular}{|lllll|}
\hline $\begin{array}{l}\text { County } \\
\text { Hygienic practice }\end{array}$ & Bomet & Nakuru & Nyeri & Total \\
\hline Source of water & & & & \\
\hline Tap/ pipe & 10.7 & 21.4 & 80.2 & 35.6 \\
\hline Well & 50.2 & 46.5 & 11.3 & 35.6 \\
\hline River & 39.1 & 32.1 & 8.5 & 26.0 \\
& & & & \\
\hline Frequency of cleaning & & & & \\
Milking containers & & & & \\
\hline Always & 80.7 & 100 & 100 & 93.2 \\
\hline Most often & 19.2 & 0.0 & 0.0 & 6.8 \\
& & & & \\
\hline Cleaning udder & & & & \\
\hline Hand & 42.3 & 0.0 & 9.2 & 17.8 \\
\hline Cleaning cloth & 57.7 & 100 & 80.8 & 82.2 \\
\hline
\end{tabular}

In Nyeri, there was a significant association $\left(X^{2}=2.41, p<0.05\right)$ between the gender of respondents and cleaning of milking containers.

\section{Knowledge on hygiene and milk handling practices}

Table 4 shows that $38.4 \%$ of all interviewed farmers found it ok to feed Spoiled feed to their cows. This practice was also found by Kiama et al. (2016) in Kenya, where farmers commonly fed Spoiled maize and food to their animals thereby increasing the risk of exposure of mycotoxins to the animals. There was no significant difference $(p>0.05)$ on the dangers of feeding spoilt feed to cows in the counties. Notably, more than half (58.6\%) of farmers in Nyeri said that it was okay to feed Spoiled feed to cows which would be an issue of concern on milk quality (Table 4). There was no significant difference ( $p>$ 
$0.05)$ in hygienic milking and delivering milk promptly as ways of ensuring milk did not spoil in the three counties. There was also no significant difference $(p>0.05)$ in knowledge of mastitis where most farmers in the counties knew the disease and could detect it in cows. There was a significant difference $(p<0.05)$ in adulteration and density as causes of milk rejection in the three counties. Most farmers (34.6\%) in Bomet thought that milk adulteration would lead to rejection on delivery while $44.5 \%$ and $41.3 \%$ in Nakuru and Nyeri, respectively, thought that addition of water to alter the density would lead to milk rejection on delivery.

Table 4 Knowledge on Hygiene and Handling Practices by Farmers (percent respondents) in the various counties

\begin{tabular}{|c|c|c|c|c|}
\hline \multicolumn{5}{|l|}{ Knowledge on hygiene } \\
\hline \multicolumn{5}{|l|}{ Is it okay to feed spoilt feed to cows } \\
\hline Yes & 30.4 & 32.0 & 58.6 & 38.4 \\
\hline No & 69.6 & 68.0 & 41.4 & 61.6 \\
\hline \multicolumn{5}{|l|}{$\begin{array}{l}\text { How do you ensure that milk does not } \\
\text { get spoiled during storage }\end{array}$} \\
\hline Boiling & 15.4 & 14.6 & 19.2 & 15.1 \\
\hline Cover container & 7.6 & 19.7 & 42.3 & 23.3 \\
\hline Deliver promptly & 34.6 & 5.9 & 15.4 & 19.2 \\
\hline Hygienic milking & 3.8 & 17.6 & 3.8 & 8.2 \\
\hline Store in a cool place & 15.4 & 5.9 & 3.8 & 8.2 \\
\hline Do Nothing & 23.1 & 36.3 & 15.4 & 26.0 \\
\hline \multicolumn{5}{|l|}{ What are the causes of milk rejection on delivery } \\
\hline Acidity & 3.8 & 5.6 & 3.8 & 4.1 \\
\hline $\begin{array}{l}\text { Organoleptic (smell, temperature, visible foreign } \\
\text { particles) }\end{array}$ & 17.3 & 5.6 & 3.8 & 9.6 \\
\hline Low density (water addition) & 15.4 & 44.5 & 41.3 & 30.1 \\
\hline $\begin{array}{l}\text { Adulteration (using other substances except } \\
\text { water) }\end{array}$ & 34.6 & 12.5 & 23.2 & 23.3 \\
\hline Others & 11.5 & 11.5 & 12.5 & 17.8 \\
\hline Don't know & 17.3 & 9.2 & 15.4 & 15.1 \\
\hline \multicolumn{5}{|l|}{ Can you detect mastitis in cows } \\
\hline Yes & 95.7 & 84.0 & 86.2 & 89.0 \\
\hline No & 4.3 & 16.0 & 13.8 & 11.0 \\
\hline
\end{tabular}


In Nakuru, there was an association $\left(X^{2}=26.809, p<0.05\right)$ between the level of education of respondents and their knowledge on the causes of milk rejection on delivery.

\section{Microbial quality of milk in different collection channels}

\section{Microbial quality of milk from Bomet county}

In the cooperatives channel, After Cooler milk samples from Coop 2 recorded the highest TVC ( $8.1 \mathrm{log}$ cfu/ml), while After Cooler samples from Coop 1 had the lowest counts of $6.8 \mathrm{log} \mathrm{cfu} / \mathrm{ml}$ (Table 5). There was, however, no significant difference $(p>0.05)$ among the samples along the channel. The level of TVC in all counties exceeded the $6.3 \mathrm{log} \mathrm{cfu} / \mathrm{ml} \mathrm{set}$ standard (EAC, 2018).

Milk samples from direct suppliers had the highest $S$. aureus counts (5.3 log cfu/ml) while First Bulk milk samples from Coop 1 had the lowest counts $(3.5 \mathrm{log} \mathrm{cfu} / \mathrm{ml})$. There was a significant difference $(p<0.05)$ in the counts in milk samples supplied directly by farmers and those from Coop 1. However; there was no significant difference $(p>0.05)$ in milk samples supplied directly by farmers and those from Coop 2. Apart from First Bulk and After Cooler milk samples of Coop 1 which met the set standard of $4.7 \mathrm{log} \mathrm{cfu} / \mathrm{ml}$ (EAC, 2018), the rest exceeded the standards.

Table 5 Microbial quality of milk in Bomet County along the collection channels

\begin{tabular}{|lllll|}
\hline Microbial attribute & S. aureus & E. coli & L.monocytogenes & TVC \\
\hline Collection channels & & & & \\
\hline Direct suppliers & $5.315 \pm 0.6^{\mathrm{b}}$ & $3.268 \pm 1.2^{\mathrm{b}}$ & $5.641 \pm 0.8^{\mathrm{a}}$ & $7.612 \pm 0.6^{\mathrm{a}}$ \\
\hline Coop 1 First bulk & $3.518 \pm 0.0^{\mathrm{a}}$ & $2.739 \pm 0.1^{\mathrm{ab}}$ & $6.622 \pm 0.0^{\mathrm{a}}$ & $6.851 \pm 0.0^{\mathrm{a}}$ \\
\hline Coop 1 After Cooler & $3.643 \pm 0.1^{\mathrm{a}}$ & $0 \pm 0^{\mathrm{a}}$ & $6.874 \pm 0.0^{\mathrm{a}}$ & $6.771 \pm 0.0^{\mathrm{a}}$ \\
\hline Coop 2 First Bulk & $5.058 \pm 0.0^{\mathrm{ab}}$ & $3.498 \pm 0.0^{\mathrm{b}}$ & $6.005 \pm 0.0^{\mathrm{a}}$ & $7.924 \pm 0.0^{\mathrm{a}}$ \\
\hline Coop 2 After Cooler & $4.475 \pm 0.1^{\mathrm{ab}}$ & $5.071 \pm 0.0^{\mathrm{b}}$ & $6.249 \pm 0.0^{\mathrm{a}}$ & $8.095 \pm 0.0^{\mathrm{a}}$ \\
\hline Coop 2 After Transport & $4.198 \pm 0.0^{\mathrm{ab}}$ & $4.541 \pm 0.1^{\mathrm{b}}$ & $6.848 \pm 0.0^{\mathrm{a}}$ & $7.686 \pm 0.0^{\mathrm{a}}$ \\
\hline
\end{tabular}

Results are mean of duplicate samples \pm standard deviation; TVC = Total Viable Counts

Means with the same letters in superscript in the same column are not significantly different at $p<0.05$

E. coli counts varied significantly depending on the collection channel with milk from After Cooler samples of Coop 2 recording the highest counts $(5.1 \mathrm{log} \mathrm{cfu} / \mathrm{ml})$ while After Cooler samples from Coop 1 had the lowest counts (0 log cfu/ml). There was no significant difference $(p>0.05)$ between First Bulk and After Cooler milk samples from Coop $1(p<0.05)$. All samples along the channel met the set standards of $4 \mathrm{log} \mathrm{cfu} / \mathrm{ml}$ (EAC 2018) with the exception of After Cooler samples of Coop 2.

There were no significant $(p>0.05)$ variations in L. monocytogenes counts along the collection channels. Milk samples from direct suppliers had the lowest counts (5.6 log cfu/ml), while After Cooler samples from Coop 1 had the highest counts (6.9 $\log \mathrm{cfu} / \mathrm{ml}$ ). It was noted that from the two cooperatives, After Cooler and After Transport milk samples had higher counts than First Bulk milk samples. 
Total viable counts varied significantly $(\mathrm{p}<0.05)$ where After Transport samples from Coop 4 had the highest counts $(9.5$ log $\mathrm{cfu} / \mathrm{ml}$ ) while After Transport samples from Coop 3 had the lowest counts of $7.4 \mathrm{log} \mathrm{cfu} / \mathrm{ml}$ (Table 6). All samples exceeded the set standards of $6.3 \mathrm{log} \mathrm{cfu} / \mathrm{ml}$ (EAC 2018).

Table 6: Microbial quality of milk in Nakuru in the along the collection channels

\begin{tabular}{|lllll|}
\hline Microbial attribute & E. coli & L.monocytogenes & S. aureus & TVC \\
\hline Collection Channel & & & & \\
\hline Direct Suppliers & $3.948 \pm 1.2^{\mathrm{ab}}$ & $5.789 \pm 0.5^{\mathrm{b}}$ & $4.734 \pm 1.1^{\mathrm{a}}$ & $8.378 \pm 1.0^{\mathrm{abc}}$ \\
\hline Traders & $4.469 \pm 0.8^{\mathrm{abc}}$ & $4.605 \pm 2.5^{\mathrm{b}}$ & $5.11 \pm 1.2 \mathrm{a}$ & $9.13 \pm 0.3^{\mathrm{bd}}$ \\
\hline Coop 3 First bulk & $6.01 \pm 0.0^{\mathrm{abc}}$ & $7.039 \pm 0.0^{\mathrm{b}}$ & $6.258 \pm 0.0^{\mathrm{a}}$ & $9.444 \pm 0.0^{\mathrm{abcd}}$ \\
\hline Coop 3 After Cooler & $6.348 \pm 0.0^{\mathrm{ac}}$ & $6.585 \pm 0.0^{\mathrm{b}}$ & $6.276 \pm 0.0^{\mathrm{a}}$ & $9.193 \pm 0.0^{\mathrm{abcd}}$ \\
\hline Coop 3 After Transport & $3.379 \pm 0.1^{\mathrm{a}}$ & $0 \pm 0.0^{\mathrm{a}}$ & $3.726 \pm 0.1^{\mathrm{a}}$ & $7.391 \pm 0.0^{\mathrm{a}}$ \\
\hline Coop 4 First Bulk & $4.911 \pm 0.0^{\mathrm{abc}}$ & $5.885 \pm 0.1^{\mathrm{b}}$ & $6.05 \pm 0.0^{\mathrm{a}}$ & $8.325 \pm 0.0^{\mathrm{ab}}$ \\
\hline Coop 4 After Cooler & $5.94 \pm 0.1^{\mathrm{abc}}$ & $6.017 \pm 0.0^{\mathrm{b}}$ & $6.082 \pm 0.0^{\mathrm{a}}$ & $8.927 \pm 0.0^{\mathrm{abcd}}$ \\
\hline Coop 4 After Transport & $5.949 \pm 0.0^{\mathrm{abc}}$ & $6.626 \pm 0.1^{\mathrm{b}}$ & $6.299 \pm 0.0^{\mathrm{a}}$ & $9.458 \pm 0.0^{\mathrm{abcd}}$ \\
\hline
\end{tabular}

Results are mean of duplicate samples \pm standard deviation; TVC = Total Viable Counts

Means with common letters in superscript in the same column are not significantly different at $p<0.05$

There were no significant $(p>0.05)$ variations in $S$. aureus counts along the collection channels. After Transport milk samples from Coop 4 had the highest counts $(6.3 \mathrm{log} \mathrm{cfu} / \mathrm{ml})$ together with After Cooler and First Bulk samples from Coop 3 (6.3 log $\mathrm{cfu} / \mathrm{ml})$. After Transport samples from Coop $3 \mathrm{had}$ the lowest counts $(3.7 \mathrm{log} \mathrm{cfu} / \mathrm{ml})$ and the only one that met the set standard of $4.7 \mathrm{log} \mathrm{cfu} / \mathrm{ml}$.

There were no significant $(p>0.05)$ variations in E. coli counts along the collection channels. After Cooler milk samples from Coop 3 had the highest counts (6.3 log cfu/ $\mathrm{ml}$ ) while After Transport samples from the same cooperative had the lowest counts $(3.4 \log \mathrm{cfu} / \mathrm{ml})$. Milk samples from direct suppliers, traders and Coop 3 After Transport are the only ones that met the set standards of $4 \log \mathrm{cfu} / \mathrm{ml}$.

There was a significant $(p<0.05)$ variation in After Transport samples from Coop 3 with the rest of the samples in $L$. monocytogenes counts along the collection channels. First Bulk milk samples from Coop 3 had the highest counts (7.0 log $\mathrm{cfu} / \mathrm{ml})$, while After Transport samples from the same cooperative had the lowest counts (0 log cfu/ml).

\section{Microbial quality of milk in Nyeri county}

There were no significant $(p>0.05)$ variations in TVC along the collection channels (Table 7). First Bulk Milk samples from Coop 5 had the highest counts $(9.4 \mathrm{log} \mathrm{cfu} / \mathrm{ml}$ ) while First Bulk samples from Coop 7 had the lowest counts (8.3 log cfu/ml). All samples exceeded the set standard of $6.3 \mathrm{log} \mathrm{cfu} / \mathrm{ml}$ (EAC 2018).

Table 7 Microbial quality of milk in Nyeri along the collection channels 


\begin{tabular}{|lllll|}
\hline Microbial attribute & E. coli & L.monocytogenes & S. aureus & TVC \\
Collection Centre & & & & \\
\hline Direct Suppliers & $5.068 \pm 1.7^{\mathrm{a}}$ & $5.552 \pm 1.3^{\mathrm{a}}$ & $4.463 \pm 0.7^{\mathrm{a}}$ & $8.537 \pm 0.6^{\mathrm{a}}$ \\
\hline Coop 5 First Bulk & $6.291 \pm 0.0^{\mathrm{a}}$ & $7.135 \pm 0.0^{\mathrm{a}}$ & $6.052 \pm 0.0^{\mathrm{b}}$ & $9.438 \pm 0.0^{\mathrm{a}}$ \\
\hline Coop 5 After Transport & $7.172 \pm 0.0^{\mathrm{a}}$ & $5.148 \pm 0.1^{\mathrm{a}}$ & $6.035 \pm 0.0^{\mathrm{b}}$ & $9.365 \pm 0.0^{\mathrm{a}}$ \\
\hline Coop 6 First Bulk & $4.017 \pm 0.1^{\mathrm{a}}$ & $5.611 \pm 0.1^{\mathrm{a}}$ & $6.394 \pm 0.0^{\mathrm{b}}$ & $9.304 \pm 0.0^{\mathrm{a}}$ \\
\hline Coop 6 After Transport & $3.952 \pm 0.1^{\mathrm{a}}$ & $5.724 \pm 0.0^{\mathrm{a}}$ & $5.208 \pm 0.0^{\mathrm{ab}}$ & $9.32 \pm 0.0^{\mathrm{a}}$ \\
\hline Coop 7 First Bulk & $3.239 \pm 0.3^{\mathrm{a}}$ & $5.707 \pm 0.0^{\mathrm{a}}$ & $4.536 \pm 0.1^{\mathrm{ab}}$ & $8.284 \pm 0.1^{\mathrm{a}}$ \\
\hline Coop 7 After Cooler & $3 \pm 0^{\mathrm{a}}$ & $8.017 \pm 0.0^{\mathrm{a}}$ & $4.573 \pm 0.0^{\mathrm{ab}}$ & $8.442 \pm 0.0^{\mathrm{a}}$ \\
\hline Coop 7 After Transport & $4.677 \pm 0.1^{\mathrm{a}}$ & $7.851 \pm 0.0^{\mathrm{a}}$ & $4.806 \pm 0.0^{\mathrm{ab}}$ & $9.037 \pm 0.0^{\mathrm{a}}$ \\
\hline
\end{tabular}

Results are mean of duplicate samples \pm standard deviation; TVC = Total Viable Counts

Means with common letters in superscript in the same column are not significantly different at $p<0.05$

Milk samples from direct suppliers varied significantly $(p<0.05)$ with samples from Coop 5. First Bulk samples from Coop 6 had the highest $S$. aureus counts $(6.4 \mathrm{log} \mathrm{cfu} / \mathrm{ml})$, while samples from direct suppliers had the lowest counts $(4.5 \mathrm{log} \mathrm{cfu} / \mathrm{ml})$. Milk samples from direct suppliers, Coop 7 First Bulk and After Cooler are the only ones that had counts below the set standard of $4.7 \mathrm{log} \mathrm{cfu} / \mathrm{ml}$ (EAC 2018) while the rest exceeded the set standards.

There were no significant $(p>0.05)$ variations in E. coli counts along the collection channels. After Transport samples from Coop 5 had the highest counts $(7.2 \mathrm{log} \mathrm{cfu} / \mathrm{ml})$, while After Cooler samples from Coop 7 had the lowest counts (3 log cfu/ml). Milk samples from direct suppliers, Coop 5 First Bulk and Coop 5 After Transport exceeded the set standard of 4 log cfu/ml (EAC 2018) while the rest met the set standards.

There were no significant $(p>0.05)$ variations in L. monocytogenes counts along the collection channels. After Cooler milk samples from Coop 7 had the highest counts $(8.0 \mathrm{log} \mathrm{cfu} / \mathrm{ml})$ followed by After Transport samples from the same cooperative (7.9 log cfu/ml), while After Transport samples from Coop 5 had the lowest counts $(5.1 \mathrm{log} \mathrm{cfu} / \mathrm{ml})$.

Cooperatives 5 and 6 had no coolers and they recorded higher TVC, S. aureus, and E. colicounts than Coop 7 which had a cooler. On the other hand, Coop 7 had higher L. monocytogenes counts than Coop 5 and 6.

\section{Comparison of milk quality across the studied counties}

Table 8 General Microbial quality of milk in different counties 


\begin{tabular}{|lllll|}
\hline Microbial attribute & TVC & E. coli & L. monocytogenes & S. aureus \\
Collection Channel & & & & \\
\hline Bomet & $7.588 \pm 0.6^{\mathrm{a}}$ & $3.253 \pm 1.3^{\mathrm{a}}$ & $5.783 \pm 0.8^{\mathrm{a}}$ & $5.132 \pm 0.7^{\mathrm{b}}$ \\
\hline Nyeri & $8.641 \pm 0.6^{\mathrm{b}}$ & $4.973 \pm 1.7^{\mathrm{b}}$ & $5.744 \pm 1.3^{\mathrm{a}}$ & $4.656 \pm 0.8^{\mathrm{a}}$ \\
\hline Nakuru & $8.72 \pm 0.8^{\mathrm{b}}$ & $4.449 \pm 1.2^{\mathrm{b}}$ & $5.298 \pm 1.9^{\mathrm{a}}$ & $5.092 \pm 1.2^{\mathrm{b}}$ \\
\hline
\end{tabular}

Results are mean of duplicate samples \pm standard deviation; TVC = Total Viable Counts

Means with common letters in superscript in the same column are not significantly different at $p<0.05$

Nakuru County recorded the highest mean TVC of $8.7 \log _{10} \mathrm{cfu} / \mathrm{ml}$, Nyeri had the highest $E$. coli mean counts of $4.97 \log _{10}$ $\mathrm{cfu} / \mathrm{ml}$ and Bomet recorded the highest mean counts of 5.13 and $5.78 \log _{10} \mathrm{cfu} / \mathrm{ml}$ for $S$. aureus and L. monocytogenes respectively (Table 8$)$.

\section{Discussion And Conclusion}

\section{Handling and hygiene practices}

In Bomet, there was a significant association between the level of education of respondents and the type of milking container they used (Table 3); where most respondents who had no formal education and those who went up to elementary school mainly used plastic containers while those who attained middle and high school education mainly used aluminium. Similar results were observed in Ethiopia by Kebede et al., (2017) where more educated farmers had better farm hygiene practices. However, this was different in Nyeri and Nakuru where the level of education of the respondents did not influence the type of container they used to store and transport milk.

Additionally, in Bomet there was a significant association between the farming system practised by respondents and cleaning of sheds where those practising intensive farming cleaned sheds more often compared to those who practised semi-intensive farming which was not the case in Nakuru and Nyeri counties.

In Nyeri County, it was noted that female respondents took better care of their milking containers as they were more likely to use both soap and water in cleaning milking containers while male respondents mostly used water only. This tendency was however not observed in Bomet and Nakuru counties. In Nakuru, there was significant association between the level of education of respondents and their knowledge on the causes of milk rejection on delivery. Most respondents who had no formal education did not know the causes of rejection, while those who had attained elementary, middle, and high school education cited various causes for rejection which was not the case in Bomet and Nyeri counties.

\section{Total Viable Counts}

TVC results in this study exceeded the set standards of $6.3 \log _{10} \mathrm{cfu} / \mathrm{ml}$ or $2 \mathrm{million} \mathrm{cfu} / \mathrm{ml}$ (EAC 2018). This could be due to various unhygienic milking and handling practices at the farm. High TVC value is an indication of raw milk that is not suitable for consumption which also indicates an increased risk of the presence of pathogenic microorganisms (Knight-jones et al. 2016). These food-borne pathogens can persist in biofilms resulting in contamination of processed milk products, especially in cases where inadequate pasteurization is done (Rola et al. 2016). A common observation in the three counties was that farmers held milk at the farm after milking without refrigeration to attend to other chores. The longer holding time in warm tropical weather results in rapid multiplication of bacteria, hence high microbial counts on delivery (Alonso et al., 2018). Nakuru county had the highest mean TVC which could have resulted from the rampant use of plastic containers for milking and storage of milk. More than half (55.6\%) of farmers in Nakuru used plastic containers compared to $13.4 \%$ and $34.6 \%$ of 
farmers in Bomet and Nyeri respectively. Plastic containers adhere to milk residues making them difficult to clean compared to aluminium containers. This shows an improvement from the situation recorded in a previous study (Ndungu et al., 2016b) where $90 \%$ and $49 \%$ of farmers in Nakuru and Nyandarua counties respectively were found to be using plastic containers for transportation of milk. The improvement could have resulted from various trainings which farmers from Nakuru County received in the last years (Ndambi et al., 2019). Ndungu et al., (2016b) further observed high mean TVC: 6.455, 6.276, 6.369, and $7.138 \log _{10} \mathrm{cfu} / \mathrm{ml}$ from milk collected from individual cans, collection routes, milk cooler and tanker respectively in Nakuru county. This study also noted that all (100\%) farmers in Nakuru often used a reusable cleaning cloth to wipe hands, equipment and udders of different cows compared to $57.7 \%$ and $80.8 \%$ of farmers in Bomet and Nyeri respectively (Table 3 ). This is a poor handling practice due to transfer of bacteria from hand to udder, hand to equipment, or between udders of various cows resulting in contamination of milk. Most farmers indicated that they rarely changed these cloths which could be sources of microbial contamination especially when not well cleaned as observed in another study in Nairobi by Wanjala et al., (2018).

High microbial counts were observed in the first bulk and after cooler milk samples from Coop 3, although milk from the same cooperative had the lowest microbial counts after it was transported to the processor in a chilling tank. This raises concerns and could be due to a number of reasons including the addition of hydrogen peroxide which has microcidal properties, thus lowering the number of microorganisms in the milk that arrived at the processor (Wallace, 2008). Microorganisms in milk of high bacteria load could form toxins which are heat resistant and can survive through processing making them present in the end product (Ozer \& Yaman, 2014; Meunier-Goddik \& Sandra 2011).

Cooperatives without coolers had higher microbial counts than those with coolers. Long holding time at these cooperatives with no cooling could encourage rapid microbial growth (Velázquez-ordoñez et al. 2019). The increase in microbial growth observed between the first bulk and after cooler samples for cooperatives with coolers could be due to poor cooling efficiency,

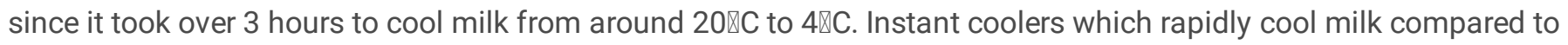
conventional coolers thus reducing the multiplication of bacteria are recommended for cooperatives (Ndungu et al., 2016b). In addition, quality-based milk payment systems could be promoted as they would stimulate farmers to improve hygienic practices (Özkan Gülzari et al., 2020; Ndambi et al., 2019).

\section{Staphylococcus aureus}

Most of the Staphylococcus aureus counts in this study exceeded the set standards where the acceptable limit is 10,000 $\mathrm{cfu} / \mathrm{ml}$ or $4 \mathrm{log} \mathrm{cfu} / \mathrm{ml}$ (EAC 2018). It was observed in the three counties that over $95 \%$ of farmers milk manually or by hand, which could be a source of $S$. aureus contamination especially when hands are not properly cleaned considering that humans are carriers of the microorganism (Orregård 2013). Direct suppliers in Bomet recorded the highest $S$. aureus counts which could be as a result of hand cleaning of the udders as done by $42.3 \%$ of farmers in the county compared to $0 \%$ and $9.2 \%$ of farmers in Bomet and Nyeri respectively (Table 3). It was also observed that these farmers washed their hands simply with cold water before milking which does not guarantee effective cleaning of hands. This agrees with a study done by (Orregård 2013) in Kiambu county in Kenya where high S. aureus counts in $70 \%$ of the samples was attributed to hand cleaning of the udders. S. aureus is an organism associated with mastitis (Wallace, 2008) which explains the high counts in Nakuru and Nyeri counties where all (100\%) farmers did not set aside cows with mastitis resulting in contamination of milk compared to $53.8 \%$ of farmers in Bomet.

Cooperatives in Nakuru County recorded the highest $S$. aureus counts. Untidy platforms, inefficient cleaning of the coolers, and poor personnel hygiene as observed at the cooperatives could be sources of milk contamination (Wallace, 2008).

Cooperative 5 in Nyeri also recorded high $S$. aureus counts. This cooperative received milk from farmers and held it without cooling for a few hours before it was delivered to the processors still without refrigeration, a practice which results in rapid multiplication of bacteria. This study agrees with one done by Wanjala et al., (2017) where mean S. aureus counts were 5.83, 6.32, and $5.82 \log _{10} \mathrm{cfu} / \mathrm{ml}$ in raw milk collected from Kenyan rural, urban and slum areas respectively all exceeding the set standards. However, the results in this study were higher than those found in a study done in Bangladesh where $S$. aureus

Page $13 / 19$ 
counts in raw milk samples from farms, chilling centres, and traders were 2.90, 2.77 and $2.78 \mathrm{log} \mathrm{cfu} / \mathrm{ml}$ respectively (Islam et al. 2016).

\section{Escherichia coli}

High E. coli counts in raw milk can be attributed to poor farm or herd hygiene (Gemechu et al., 2015). Direct suppliers in Bomet had high $E$. coli counts which could be attributed to the fact that $80.8 \%$ of farmers in the area rarely cleaned sheds or disposed dung compared to $19.2 \%$ and $33.3 \%$ of farmers in Nyeri and Nakuru respectively, resulting in mud and faeces being sources of contamination within addition, hand cleaning of the udders as practised by $42.3 \%$ of farmers in Bomet compared to none $(0 \%)$ and $9.2 \%$ of farmers in Nakuru and Nyeri respectively. This practice does not guarantee efficient cleaning, thus compromising milk quality. High E. coli counts in Bomet and Nakuru counties could have resulted from contaminated water. It was observed that $50.2 \%$ and $46.5 \%$ of farmers in Bomet and Nakuru counties respectively, sourced water from wells while $39.1 \%$ and $32.1 \%$ of farmers from the same counties sourced water from rivers and used the water for cleaning and feeding the cattle without any form of treatment. Farmers in the three counties cited that density or addition of water was a cause of milk rejection on delivery to the processor. Presence of $E$. coli in raw milk samples that were aseptically collected from the three counties can indicate the use of contaminated water in cases of milk adulteration as observed by Amenu et al.' (2016) in southern Ethiopia. The high E. coli counts coincide with a study done by (Alonso et al. 2018), where the median coliform count of raw milk samples consumed in households in Nairobi was 3 million cfu/ml exceeding the set standard of 50,000 $\mathrm{cfu} / \mathrm{ml}$ (EAC 2018). In Asia, Koirala (2018) did a study on raw milk samples in Pokhara where total coliform counts of samples at farm level ranged from $0-1.2 * 10^{5} \mathrm{cfu} / \mathrm{ml}$ while those from milk collection centres had a mean count of $3.4^{\star} 10^{4}$ $\mathrm{cfu} / \mathrm{ml}$. Presence of $E$. coli indicates the presence of other coliforms and is an indicator of faecal contamination and thus posing great safety and public health concerns (Wallace, 2008). Raw milk which has high E.coli contamination develops offflavour fast even after processing, hence reduced shelf life of dairy products (Reta and Addis 2015).

\section{Listeria monocytogenes}

It has been noted that L. monocytogenes is the only Listeria that has pathogenic effects in healthy humans and when products such as cheese are made from infected raw milk, bacterial growth occurs resulting in a highly contaminated product which causes listeriosis on consumption (Wallace, 2008). Listeriae are commonly found in the environment (Ulusoy and Chirkena 2019). Generally, Bomet County recorded the highest L. monocytogenes counts likely because more of their animals were allowed to graze which could be a source of contamination compared to those in Nakuru and Nyeri. The most common source of L. monocytogenes infection in dairy cows is from poorly preserved silage (Seyoum et al., 2015). Direct suppliers in Nyeri and Nakuru counties recorded high L. monocytogenes counts where $58.6 \%$ and $32 \%$ of farmers in the respective counties cited that it was okay to give Spoiled feed to dairy cows, a practice which results in contamination of milk. Cooperatives in the three counties especially those with coolers recorded high L. monocytogenes count for the After Cooler and After Transport samples. L. monocytogenes has the ability to survive in temperatures as low as $4 \llbracket \mathrm{C}$ in already contaminated milk hence the high numbers of the samples contamination levels in this study were higher compared to those found in Ethiopia where $18.9 \%$ of raw milk samples were found to be contaminated by L. monocytogenes at the farm level (Seyoum et al. 2015). This could be due to the fact that farmers in Ethiopia mostly practised intensive dairy farming thus minimizing contamination of milk.

Based on the findings of this study, farmers in the three counties did not employ good hygienic practices in dairy management. Milking was done with little consideration on measures to ensure quality. Farmers used plastic containers for milking and storage of milk; they rarely cleaned sheds and did not set aside cows with mastitis. These unhygienic practices resulted in poor microbial quality of raw milk supplied by farmers and along collection channels. In most samples, the average TVC, E. coli, S. aureus, and L. monocytogenes counts in all counties exceeded the set Kenyan standards. High bacteria counts poses a health risk to consumers considering that most of these microorganisms form toxins which are heat resistant and can survive processing temperatures and conditions making their way to the end product. Constant training for farmers and cooperative personnel on hygienic practices and milk handling is required coupled with improvement of road 
infrastructure, installation of instant coolers at cooperatives to further reduce the multiplication of bacteria. Moreover, the use of a quality-based system for milk payment could provide farmers incentives to improve milk quality.

\section{Declarations}

\section{Data Availability}

Raw survey data is available upon request.

\section{Conflict of Interests}

The authors declare that there are no conflicts of interests for this article.

\section{AUTHOR CONTRIBUTIONS}

MM, GO, AN and JM conceived and designed the research

MM collected samples, did laboratory analysis and wrote the draft manuscript

MM and GO analysed the data

AN and JM contributed in the interpretation of results

All authors approved of the Manuscript

\section{ACKNOWLEDGEMENTS}

Special thanks to Wageningen University \& Research for supporting this study under the Africa-Milk Project, funded by the LEAP-AGRI partnership. The authors also thank Jacinta Muchiri and Jared Omondi for laboratory assistance.

\section{References}

1. Alonso S, Grace D. 2018. Food safety as a pathway to nutrition: the MoreMilk project Food safety, Agenda 2030 and the SDGs. In: Webinar- DFID Nutrition Hub.

2. Alonso S, Varnell H, Keefe R, Wainaina M, Roesel K, Grace D. 2018. Is my milk safe? Quality and safety of the milk consumed in low-income households in Nairobi. The 15th International Symposium on Veterinary Epidemiology and Economics Chiang Mai, Thailand, (November).

3. Amenu K, Shitu D, Abera M. 2016. Microbial contamination of water intended for milk container washing in smallholder dairy farming and milk retailing houses in southern Ethiopia. Springerplus. 2016;5(1):1195. Published 2016 Jul 28. doi:10.1186/s40064-016-2841-x

4. Bebe BO, Lee J Van Der, Kilelu CW. 2018. Milk Retailing Innovation in Kenya and Consumers Perceptions of Safety. :14. https://edepot.wur.nl/496519

5. Bonilla J, McCarthy N, Mugatha S, Rai N, Coombes A, Brubaker J. 2018. Impact evaluation of the Smallholder Dairy Commercialization Programme in Kenya. (May). https://doi.org/10.23846/tw4IE73

6. Brown LH, Alonso S, Lindahl J, Varnell H, Hoffmann V. 2018. Awareness and Compliance among Farmers and Vendors. http://ebrary.ifpri.org/utils/getfile/collection/p15738coll2/id/133046/filename/133255.pdf

7. GeoCurrents Map. 2020. The administrative counties of Kenya. https://images.app.goo.gl/8FT4bDEi5s1wdnsw9 Accessed 31.07.2020

8. CGOB. 2019. County Government of Bomet. https://bomet.go.ke/

9. CGON. 2020. County Government of Nakuru. https://nakuru.go.ke/. 
10. CGONY. 2019. About Nyeri - County Government of Nyeri. http://www.nyeri.go.ke/.

11. EAC. 2006. Standards for raw cow milk. https://law.resource.org/pub/eac/ibr/eas.67.2006.html

12. EAC. 2018. Draft East African Standards on Raw

Milk. https://members.wto.org/crnattachments/2018/SPS/KEN/18_3085_00_e.pdf

13. Gemechu T, Beyene F, Eshetu M. 2015. ISABB-Journal of Food and Agricultural Science Physical and chemical quality of raw cow's milk produced and marketed in Shashemene Town, Southern Ethiopia. 5(2):7-13. doi:10.5897/ISABBJFAS2014.0017.

14. Islam A, Mohammad H, Science D, Mahmud MS. 2016. Microbial analysis of raw and pasteurized milk from selected areas of Dinajpur, Bangladesh. Asian Journal of Medical and Biological Research, 1(2)(January), 292-296.

https://doi.org/10.3329/ajmbr.v1i2.25624

15. KDB. 2020. Dairy Industry Produce Safety Regulations. https://www.kdb.go.ke/wp-content/uploads/2020/02/8.- DAIRY INDUSTRY-DAIRY-PRODUCE-SAFETY-REGULATIONS. pdf

16. Kebede GL, Megerrsa SA. 2017. Assessment of dairy farmers' hygiene milking practices and awareness on cattle milkborne zones in Bishoftu, Ethiopia. Journal of Veterinary Medicine and Animal Health. Vol. 10(2), pp. 45-

54 https://doi.org/10.5897/JVMAH2017.0602

17. KNBS. 2020. Kenya Population and Housing Cencus. https://www.knbs.or.ke/?p=5621

18. Knight-jones TJD, Hang MB, Songe MM, Sinkala Y, Grace D. 2016. Microbial Contamination and Hygiene of Fresh Cow 's Milk Produced by Smallholders in Western Zambia. International Journal of Environmental Research and Public Health Article, 13(737), 1-13. https://doi.org/10.3390/ijerph13070737.

19. Koirala S, Timilsina P, Chhetri1 J, Khanal H, Khadka A, Koirala U. 2018. Quality and safety assessment of milk supply chain in Pokhara: A case study. ResearchGate, (February).

20. Ndambi A, Kilelu CW, van der Lee J, Njiru R, Koge J. 2019. Making milk quality assurance work on an unlevel playing field. In 3R Research Report 008 WLR. Nairobi. https://edepot.wur.nl/476559

21. Ndungu TW, Muliro PS, Omwamba M, Oosterwijk G, Jansen A. 2016a. Quality control of raw milk in the smallholder collection and bulking enterprises in Nakuru and Nyandarua Counties, Kenya. African J Food Sci. 10(May):70-78. doi:10.5897/AJFS2015.1412.

22. Ndungu TW, Omwamba M, Muliro PS, Oosterwijk G. 2016b. Hygienic practices and critical control points along the milk collection chains in smallholder collection and bulking enterprises in Nakuru and Nyandarua Counties, Kenya. African Journal of Food Science, 10(11), 327-339. https://doi.org/10.5897/ajfs2016.1485

23. Odero-Waitituh JA. 2017. Smallholder dairy production in Kenya; A review. Livestocj Research for Rural Development. 29(7).

24. Orregård M. 2013. Quality analysis of raw milk along the value chain of the informal milk market in Kiambu County , Kenya. Sveriges lantbruksuniversitet Swedish University of Agricultural Sciences. https://pdfs.semanticscholar.org/8f6f/96ff17f7e84a021315aa9a5e6b1919d2cbc5.pdf

25. Özkan Gülzari Ş, Owade JO, Ndambi OA. 2020. A review of interventions and parameters used to address milk quality in eastern and southern Africa. Food Control, 116, [107300]. https://doi.org/10.1016/j.foodcont.2020.107300

26. Reta MA, Addis AH. 2015. Microbiological Quality Assessment of Raw and Pasteurized Milk. Int J Food Sci Microbiol. 2(6):087-091.

27. Rola JG, Czubkowska A, Korpysa-Dzirba W, Osek J. 2016. Occurrence of Staphylococcus aureus on farms with small scale production of raw milk cheeses in poland. Toxins (Basel). 8(3). doi:10.3390/toxins8030062.

28. Seyoum ET, Woldetsadik DA, Mekonen TK, Gezahegn HA, Gebreyes WA. 2015. Prevalence of listeria monocytogenes in raw bovine milk and milk products from central highlands of Ethiopia. J Infect Dev Ctries. 9(11):1204-1209. doi:10.3855/jidc.6211. 
29. T.I.A.P.D. 2016. Report of a study on assessing the cost of production structures in dairy systems in Kenya. https://www.kdb.go.ke/wp-content/uploads/2019/06/Cost-of-milk-production-report-May-2016.pdf

30. Ulusoy BH, Chirkena K. 2019. Two perspectives of Listeria monocytogenes hazards in dairy products: the prevalence and the antibiotic resistance. Food Quality and Safety, 3(4), 233-241. https://doi.org/10.1093/fqsafe/fyz035.

31. Vara Martínez JA de la, García Higuera A, Román Esteban M, Romero Asensio J, Carmona Delgado M, Berruga I, Molina A. 2017. Monitoring bulk milk quality by an integral traceability system of milk. Journal of Applied Animal Research, 46(1), 784-790. https://doi.org/10.1080/09712119.2017.1403327

32. Velázquez-ordoñez V, Valladares-carranza B, Tenorio-borroto E, Talavera-rojas M, Varela-guerrero JA, Acosta-dibarrat J, Puigvert F, Grille L, Revello ÁG. 2019. Microbial Contamination in Milk Quality and Health Risk of the Consumers of Raw Milk and Dairy Products. In: Nutrition in Health and Disease - Our Challenges Now and Forthcoming Time. DOI:

10.5772/intechopen.8618

33. Wallace RL. 2015. Bacteria counts in raw milk.

http://livestocktrail.illinois.edu/uploads/dairynet/papers/Bacteria\%20Counts\%20in\%20Raw\%20Milk\%20DD\%202008.pdf

34. Wanjala GW, Mathooko FM, Kutima PM Mathara JM. 2017. Microbiological quality and safety of raw and pasteurized milk marketed in and around Nairobi region. African Journal of Food, Agriculture Nutrition and Devevopment.

17(1):11518-11532. doi:10.18697/ajfand.77.15320.

35. Wanjala WN, Nduko JM, Mwende MC. 2018. Coliforms Contamination and Hygienic Status of Milk Chain in Emerging Economies. Journal of Food Quality and Hazards Conrol, 5(1), 3-10. https://doi.org/10.29252/jfqhc.5.1.3.

\section{Figures}

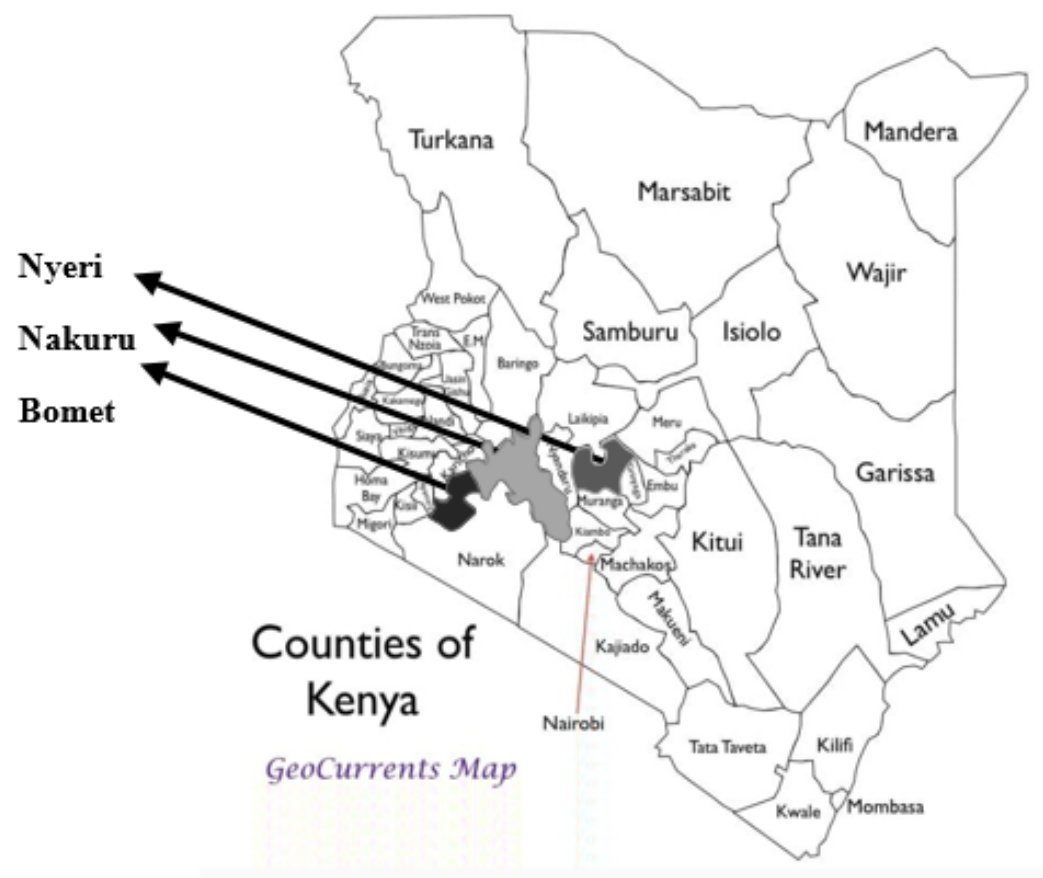

\section{Figure 1}

Map of Kenya showing Bomet, Nakuru and Nyeri counties Source: GeoCurrents Map, 2020 


\section{a) Direct suppliers}

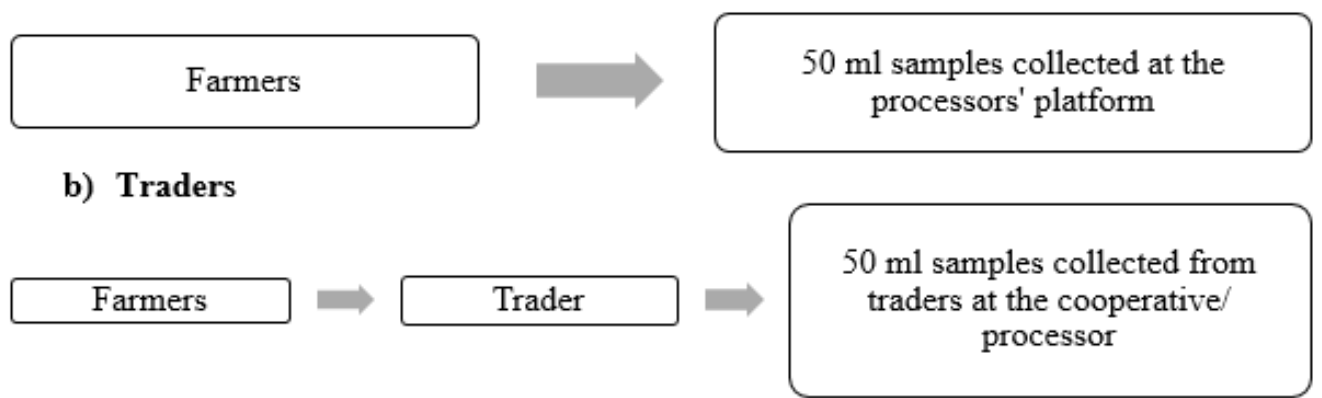

c) Cooperatives with coolers

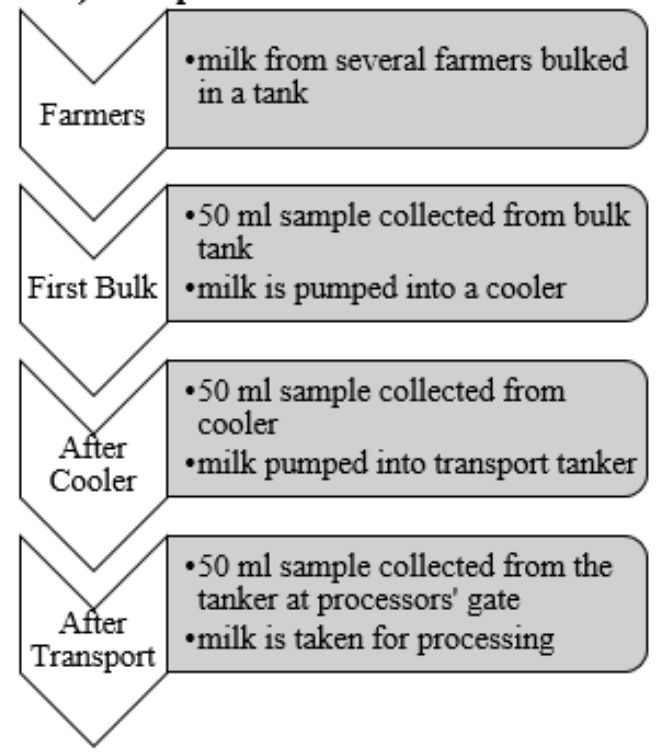

d) Cooperatives without coolers

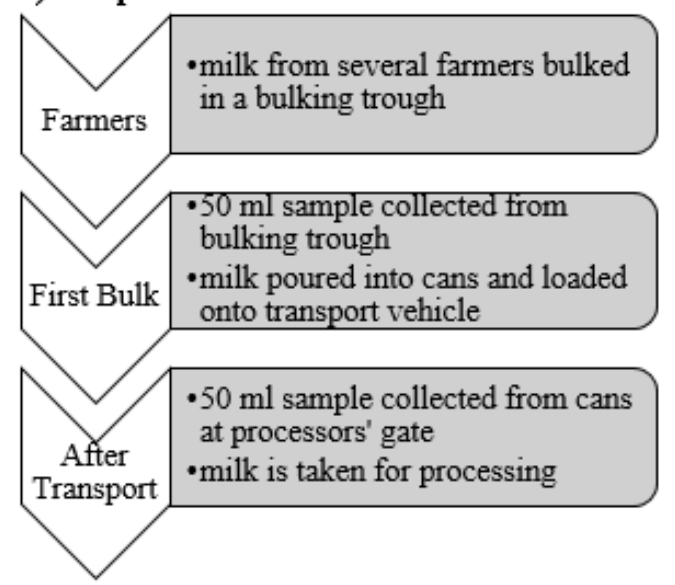

Figure 2

Procedure for obtaining milk samples

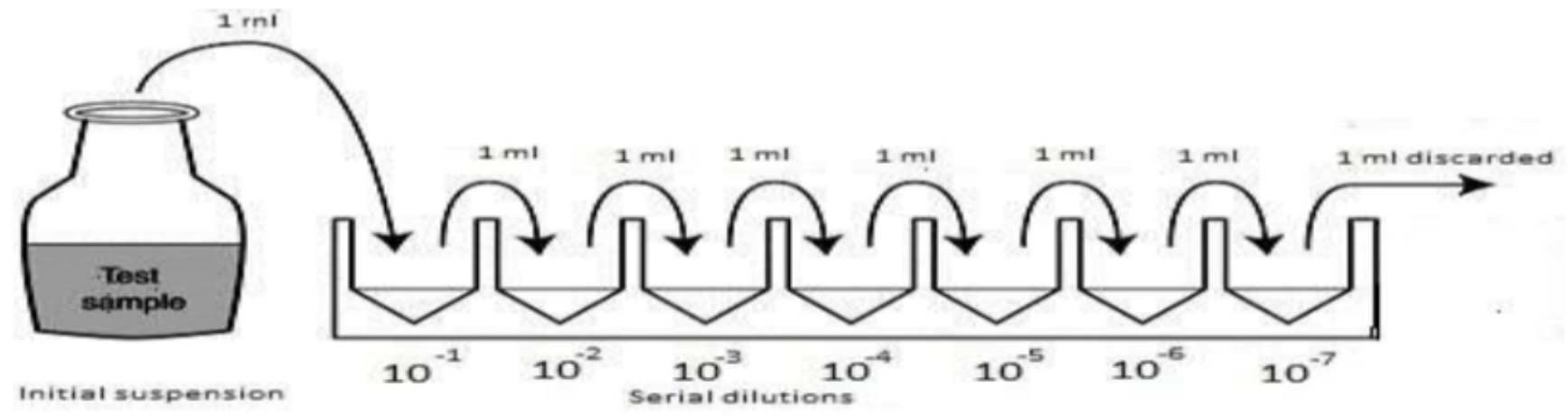

Figure 3

Procedure adopted for serial dilution of samples 


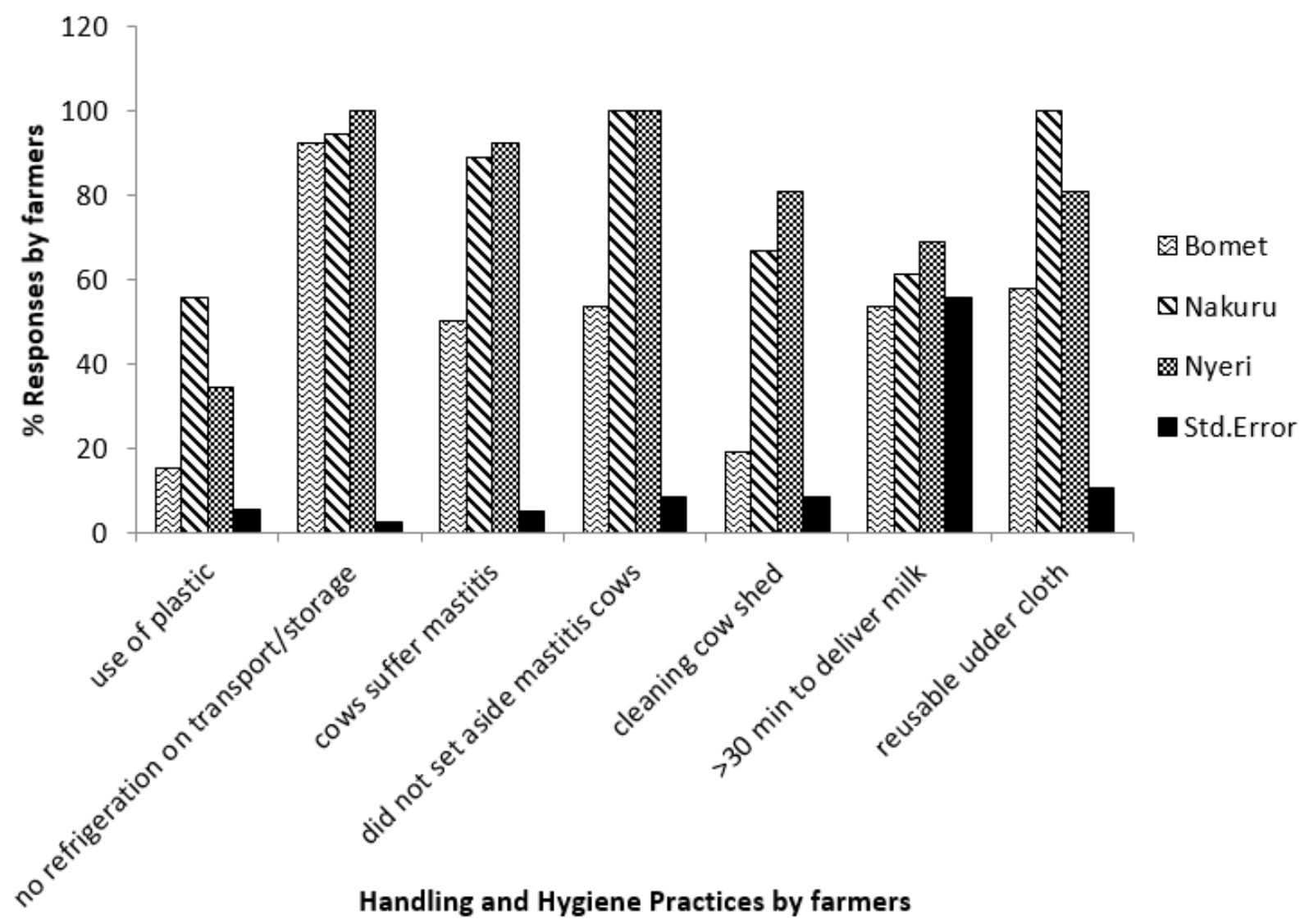

Figure 4

Handling and Hygiene Practices by farmers in Bomet, Nakuru and Nyeri counties 